\title{
Fontes de silício no controle da mancha bacteriana (Xanthomonas spp.) do tomateiro
}

\author{
Thaíssa Vitorino dos Anjos ${ }^{1}$ Nilvanira Donizete Tebaldi², Lara Caroline Borges Moreira Mota ${ }^{3}$, Lísias Coelho ${ }^{2}$
}

${ }^{1}$ Graduanda em Agronomia, ${ }^{2}$ Docentes em Agronomia, ${ }^{3}$ Técnica de Laboratório, do Instituto de Ciências Agrárias, Universidade Federal de Uberlândia, Av. Amazonas s/n, Bloco 4C-127, Campus Umuarama, CEP 38.400-902, Uberlândia, MG, Brazil

Autor para correspondência: Nilvanira Donizete Tebaldi (nilvanira@iciag.ufu.br)

Data de chegada: 22/05/2014. Aceito para publicação em: 27/10/2014.

$10.1590 / 0100-5405 / 2007$

\section{RESUMO}

Anjos, T.V,; Tebaldi, N.D.; Mota, L.C.B.M.; Coelho, L. Fontes de silício no controle da mancha bacteriana (Xanthomonas spp.) do tomateiro. Summa Phytopathologica, v.40, n.4, p.365-367, 2014.

A mancha bacteriana do tomateiro causada por quatro espécies de Xanthomonas pode provocar perdas significativas na produção da cultura e a utilização do silício na proteção de plantas tende a reduzir a incidência de doenças. O objetivo do trabalho foi avaliar fontes de silício no controle da mancha bacteriana do tomateiro. Para a avaliação da inibição do crescimento bacteriano in vitro foram utilizados discos de papel de filtro esterilizados contendo $10 \mu \mathrm{L}$ de silício coloidal ou silicato de potássio nas concentrações de 10, 30, 40 e $50 \mu \mathrm{g} \mu \mathrm{L}^{-1}$. Esses discos foram colocados sobre a bactéria cultivada em placas de Petri com meio de cultura, observando-se a formação de halos de inibição. Para avaliação da redução da severidade da mancha bacteriana do tomateiro em casa de vegetação, plantas de tomate foram pulverizadas com os produtos nas concentrações $10,20,30,40$ e $50 \mathrm{~g} \mathrm{~L}^{-1}$ e, após três dias, foi feita

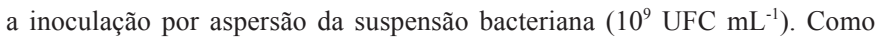
testemunhas foram utilizadas plantas pulverizadas com água destilada ou inoculadas com a suspensão bacteriana. O silício coloidal não foi eficiente no controle de Xanthomonas spp. Concentrações de 30, 40 e $50 \mu \mathrm{g} \mu \mathrm{L}^{-1}$ de silicato de potássio inibiram o crescimento bacteriano in vitro e concentrações de 40 e $50 \mathrm{~g} \mathrm{~L}^{-1}$ reduziram o índice de doença da mancha bacteriana do tomateiro.

Palavras-chave adicionais: Silicato de potássio, Xanthomonas euvesicatoria, X. gardneri, X. perforans, X. vesicatoria.

\section{ABSTRACT}

Anjos, T.V.; Tebaldi, N.D.; Mota, L.C.B.M.; Coelho, L. Silicate sources for the control of tomato bacterial spot (Xanthomonas spp.). Summa Phytopathologica, v.40, n.4, p365-367, 2014.

Tomato bacterial spot caused by four species of Xanthomonas can cause significant losses to the crop production, and the use of silicon in the protection of plants tend to reduce the disease incidence. The aim of this study was to evaluate silicon sources on the control of tomato bacterial leaf spot. To evaluate the in vitro bacterial growth inhibition, sterile paper discs containing $10 \mu \mathrm{L}$ of colloidal silicon or potassium silicate were used at the concentrations of $10,30,40$ and $50 \mu \mathrm{g} \mu \mathrm{L}^{-1}$. These discs were placed over the bacteria grown on Petri dishes containing culture medium, and the formation of inhibition zones was observed. To evaluate the reduction in the severity of tomato bacterial leaf spot in greenhouse, tomato plants were sprayed with the products at the concentrations of 10,20,30,40 and $50 \mathrm{~g} \mathrm{~L}^{-1}$ and, after three day, spray inoculation of the bacterial suspension $\left(10^{9} \mathrm{CFU} \mathrm{mL} \mathrm{m}^{-1}\right)$ was done. Control treatments consisted of plants sprayed with distilled water or inoculated with the bacterial suspension. Colloidal silicon was not effective in controlling Xanthomonas spp. Potassium silicate, at the concentrations of 30,40 and $50 \mu \mathrm{g} \mu \mathrm{L}^{-1}$, inhibited the in vitro bacterial growth and, at the concentrations of 40 and $50 \mathrm{~g} \mathrm{~L}^{-1}$, reduced tomato bacterial leaf spot disease.

Additional keywords: Potassium silicate, Xanthomonas euvesicatoria, X. gardneri, X. perforans, X. vesicatoria.

A mancha bacteriana do tomateiro é causada por quatro espécies do gênero Xanthomonas: Xanthomonas euvesicatoria, X. vesicatoria, $X$. gardneri e $X$. perforans (5). A doença ocorre frequentemente, sendo destrutiva em condições de elevada umidade, precipitação e temperatura entre 20 e $30^{\circ} \mathrm{C}(7)$.

$\mathrm{O}$ controle químico da bactéria não tem sido eficiente (8) e o fornecimento de silício vem tornando-se uma alternativa para reduzir a intensidade de doenças (12), pois além de conferir resistência da planta a determinado patógeno ou a ativação das barreiras químicas e bioquímicas da planta (3), também proporciona benefícios nutricionais e incrementa a produção e qualidade dos produtos agrícolas (11).

Este trabalho teve como objetivo avaliar fontes de silício na inibição do crescimento bacteriano in vitro e o controle da mancha bacteriana do tomateiro em casa de vegetação.

Os experimentos foram conduzidos na Universidade Federal de Uberlândia - MG, no ano de 2010. O isolado UFU A35 de Xanthomonas spp. pertencente à coleção de trabalho foi cultivado em meio de cultura 523. Após 48 h foi preparada uma suspensão bacteriana em solução de $\mathrm{NaCl} 0,85 \%$ e ajustada em espectrofotômetro para $\mathrm{OD}_{550}=0,5\left(1 \times 10^{9}\right.$ $\left.\mathrm{UFC} \mathrm{mL}^{-1}\right)$.

A toxidez direta do silício foi avaliada através do halo de inibição do crescimento bacteriano em meio de cultura, em placa de Petri, usando uma camada básica de meio agar-água $2 \%$ e outra camada contendo meio nutriente semi sólido $(0,8 \%)$ acrescida de $10 \%$ da suspensão bacteriana $\left(10^{9} \mathrm{UFC} \mathrm{mL}^{-1}\right)$. Em seguida, discos de papel de filtro esterilizados (6 $\mathrm{mm}$ de diâmetro) foram colocados sobre o 
meio e adicionados $10 \mu \mathrm{L}$ da solução de silício coloidal ou silicato de potássio esterilizados sob luz ultravioleta, nas concentrações de 10 , 30,40 e $50 \mu \mathrm{g} \mu \mathrm{L}^{-1}$, sendo ajustado o $\mathrm{pH}$ para 7,0. Para a testemunha foi utilizada água esterilizada e para o controle positivo, discos com antibiótico estreptomicina $\left(10 \mathrm{mg} \mathrm{mL}^{-1}\right)$. Foram utilizados dois discos para cada concentração e para cada tratamento. Os halos de inibição foram avaliados $48 \mathrm{~h}$ após a incubação em estufa a $28^{\circ} \mathrm{C}$.

Em casa de vegetação, plantas de tomate da cv. Santa Cruz Kada foram cultivadas em vasos com capacidade de $500 \mathrm{~mL}$, com substrato solo, areia, húmus e vermiculita (4:1:1:1). Após 15 dias da semeadura, as plantas (três a quatro folhas) foram pulverizadas até o ponto de escorrimento com silício coloidal ou silicato de potássio nas concentrações de 10, 20,30, 40 e $50 \mathrm{~g} \mathrm{~L}^{-1}$. Três dias após as pulverizações, as plantas foram inoculadas via pulverização das folhas, com suspensão bacteriana $\left(10^{9} \mathrm{UFC} \mathrm{mL}^{-1}\right)$, sendo mantidas em câmara úmida $24 \mathrm{~h}$ antes e após a inoculação. Como testemunhas foram utilizadas plantas pulverizadas com água destilada ou inoculadas com a suspensão bacteriana, sem prévia aplicação de silício. $\mathrm{O}$ delineamento experimental foi o de blocos casualizados com quatro repetições, sendo considerado como unidade experimental um vaso contendo duas plantas. As avaliações foram feitas aos 5, 8, 11, 14 e 17 dias após a inoculação. A severidade da doença foi quantificada empregando-se escala diagramática (8). Para ponderar a severidade foi aplicado o índice de McKinney (1923) (10), pela fórmula: ID (\%) $=\sum((f . v) /(n . x)) .100$, em que: ID $=$ Índice de doença; $f=$ número de plantas com determinada nota; $\mathrm{v}=$ nota observada; $\mathrm{n}=$ número total de plantas avaliadas; $\mathrm{x}=$ grau máximo de infecção. Os dados obtidos foram submetidos à análise de variância e as médias foram comparadas pelo teste de Tukey a $5 \%$ de significância.

O silicato de potássio, nas concentrações de 30,40 e $50 \mu \mathrm{g} \mu \mathrm{L}^{-1}$ e a estreptomicina formaram halo de inibição do crescimento bacteriano de Xanthomonas spp. in vitro (Figura 1). O mesmo não ocorreu para o tratamento testemunha (água) e silício coloidal nas diferentes concentrações.

Brancaglione et al. (1) também observaram que a argila silicatada inibiu $100 \%$ do crescimento bacteriano de Xanthomonas axonopodis pv. passiflorae em meio de cultura.

Em casa de vegetação, os primeiros sintomas foram observados aos cinco dias após a inoculação. As plantas pulverizadas com silício coloidal (Tabela 1), independente da concentração utilizada, não reduziram o índice da doença da mancha bacteriana do tomateiro. No entanto, as concentrações de 40 e $50 \mathrm{~g} \mathrm{~L}^{-1}$ do silicato de potássio apresentaram o menor índice de doença, 8,75 e 2,5, respectivamente, diferindo significativamente das plantas inoculadas $(17,50)$, demonstrando a eficiência do produto no controle da bactéria. Nas plantas testemunha pulverizadas apenas com água não foi constatada a presença do patógeno. O silicato de potássio reduziu a severidade da mancha bacteriana diferindo significativamente do silício coloidal.

Em estudos anteriormente realizados, o silicato de potássio mostrou-se eficiente no controle de Xanthomonas translucens pv. undulosa em plantas de trigo (2). Pesquisas sobre mancha aquosa do meloeiro, causada por Acidovorax avenae subsp. citrulli evidenciaram redução de 88,54 e 85,34\%, para o índice de doença e a área abaixo da curva de progresso da doença, respectivamente, com o uso de silicato de cálcio no solo (4).

De acordo com a literatura, o silício nas folhas está envolvido na regulagem da transpiração, concentrando-se na epiderme e formando uma barreira de resistência mecânica à invasão de bactérias (3), além da ativação das defesas químicas e bioquímicas da planta, aumentando o conteúdo de fenóis, atividade de quitinases, ß-1,3-glucanases, peroxidases, $\beta$-glicosidades, fenilamonia liase e polifenoloxidase (11).

Dentre os critérios básicos que diferenciam a indução de resistência de outros fatores, destaca-se a ausência de efeitos tóxicos do agente indutor sobre o patógeno (6). Neste trabalho foi verificada a inibição do crescimento bacteriano in vitro e apesar de não haver registro de ação direta in vitro do silício sobre bactérias, os resultados obtidos levam a sugerir provável ação bactericida do silicato de potássio no controle

Tabela 1. Índice de doença da mancha bacteriana do tomateiro, sob diferentes doses de silício coloidal e silicato de potássio. Uberlândia, UFU, 2010.

\begin{tabular}{ccc}
\hline \multirow{2}{*}{ Doses (g.L $\left.\mathrm{L}^{-1}\right)$} & \multicolumn{2}{c}{ Índice de Doença } \\
\cline { 2 - 3 } & Silício coloidal & Silicato de potássio \\
\hline Testemunha (água) & $0,00 \mathrm{a}$ & $0,00 \mathrm{a}$ \\
Testemunha (inoculada) & $23,75 \mathrm{bc}$ & $17,50 \mathrm{bc}$ \\
10 & $16,25 \mathrm{~b}$ & $27,50 \mathrm{c}$ \\
20 & $15,00 \mathrm{~b}$ & $20,00 \mathrm{bc}$ \\
30 & $18,75 \mathrm{~b}$ & $16,25 \mathrm{bc}$ \\
40 & $33,75 \mathrm{c}$ & $8,75 \mathrm{ab}$ \\
50 & $23,75 \mathrm{bc}$ & $2,50 \mathrm{a}$ \\
\hline Produtos & $21,50 \mathrm{~B}$ & $15,00 \mathrm{~A}$
\end{tabular}

\section{C.V. $(\%) \quad 37,27$}

Médias seguidas de letras iguais minúscula na coluna e maiúscula na linha não diferem entre si, pelo teste de Tukey a 5\% de significância.

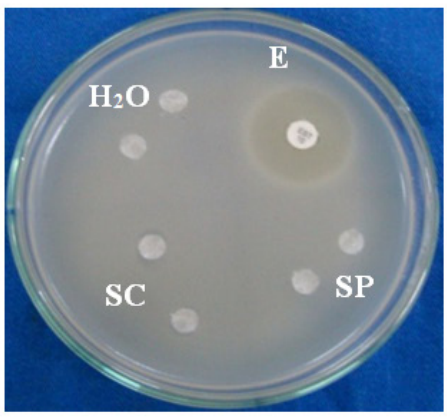

$\mathrm{H}_{2} \mathrm{O}$ e $10 \mu \mathrm{g} \mu \mathrm{L}^{-1}$

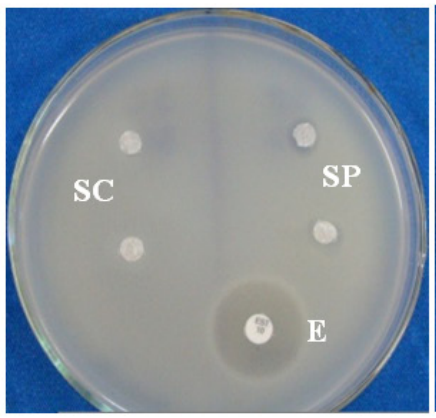

$30 \mu \mathrm{g} \mu \mathrm{L}^{-1}$

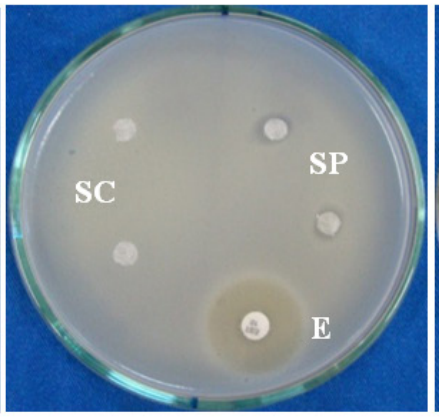

$40 \mu \mathrm{g} \mu \mathrm{L}^{-1}$

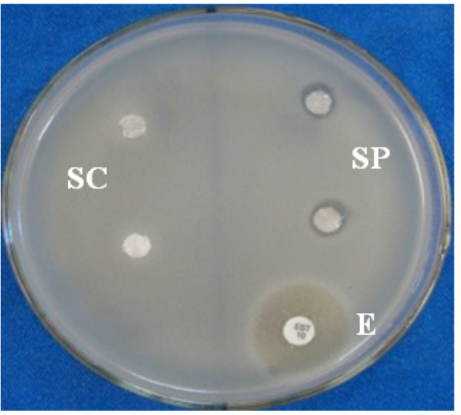

$50 \mu \mathrm{g} \mu \mathrm{L}^{-1}$

Figura 1. Presença de halos de inibição no crescimento bacteriano in vitro de Xanthomonas spp., em diferentes doses de silicato de potássio (SP) e silício coloidal (SC), água $\left(\mathrm{H}_{2} \mathrm{O}\right)$ e estreptomicina (E). Uberlândia, UFU, 2010. 
de Xanthomonas spp., além da indução de resistência já preconizada para o composto.

De acordo com os resultados obtidos, o silício coloidal não foi eficiente no controle de Xanthomonas spp. do tomateiro. Entretanto, o silicato de potássio nas concentrações de 30,40 e $50 \mu \mathrm{g} \mu \mathrm{L}^{-1}$ inibiram o crescimento bacteriano in vitro e nas concentrações de 40 e $50 \mathrm{~g} \mathrm{~L}^{-1}$ reduziram o índice de doença da mancha bacteriana do tomateiro em condições de casa de vegetação.

\section{REFERÊNCIAS BIBLIOGRÁFICAS}

1. Brancaglione, P.; Sampaio, A.C.; Fischer I.H.; Almeida, A.M.; Fumis, T.F. Eficiência de argila silicatada no controle de Xanthomonas axonopodis pv. passiflorae, in vitro e em mudas de maracujazeiro-amarelo. Revista Brasileira de Fruticultura, Jaboticabal, v.31, n.3, p.718-724, 2009.

2. Carvalho, M.P.; Silva, I.T.; Rodrigues, F.A.; Oliveira, J.R.; Zanão Filho, L.A. Silicato de potássio e acibenzolar-S-methyl no controle da estria bacteriana em trigo. Fitopatologia Brasileira, Brasília, v. 32, supl., p.226-227, 2007. (Resumo).

3. Epstein, E. Silicon. Annual Review of Plant Physiology and Plant Molecular Biology, Palo Alto, v.50, p.641-664, 1999.

4. Ferreira, H.A. Silício no controle da mancha-aquosa em meloeiro (Cucumis melo L.). 2009. 82f. Dissertação (Mestrado em Fitopatologia) - Universidade Federal Rural de Pernambuco, Recife.

5. Jones, J.B.; Lacy, G.H.; Bouzar, H.; Stall, R.E.; Schaad, N.W. Reclassis fication of the xanthomonads associated with bacterial spot disease of tomato and pepper. Systematic of Applied Microbiology, Amsterdan, v. 27, n.6, p. $755-762,2004$

6. Kessmann, H.; Staub, T.; Hofmann, C.; Maetzke, T.; Herzog, J.; Ward, E.; Uknes, S.; Ryals, J. Induction of systemic acquired disease resistance in plants by chemicals. Annual Review of Phytopathology, Palo Alto, C.32, p.439-459, 1994.

7. Kurozawa, C.; Pavan, M.A. Doenças do tomateiro (Lycopersicon esculentum). In: Kimati, H.; Amorim, L.; Rezende, J.A.M.; Bergamin Filho, A.; Camargo, L.E.A. Manual de fitopatologia: doenças das plantas cultivadas. 4.ed. São Paulo: Agronômica Ceres, 2005. v.2, p.607-626.

8. Maringoni, A.C.; Kurozawa, C.; Barbosa, V.; Silva Neto, J.M. Controle químico da mancha bacteriana (Xanthomonas campestris pv. vesicatoria (Doidge) Dye) do tomateiro (Lycopersicon esculentum Mill.). Summa Phytopatologica, Jaguariúna, v.12, n.1-2, p.92-101, 1986.

9. Mello, S.C.; Takatsu, A.; Lopes, C.A. Escala diagramática para avaliação da mancha-bacteriana do tomateiro. Fitopatologia Brasileira, Brasília, v.22, n.3, p.447-448, 1997.

10. McKinney, H.H. Influence of soil temperature and moisture on infection of wheat seedlings by Helmintosporium sativum. Journal Agricultural Research, Washington, v.26, n.5, p.195-219, 1923.

11. Nojosa, G.B.A. Efeito de indutores na resistência de Coffea arabica L. a Hemileia vastatrix Berk. \& Br. e Phoma costarricensis Echandi. 2003. 102 p. Tese (Doutorado em Fitopatologia) - Universidade Federal de Lavras, Lavras.

12. Pozza, A.A.A.; Alves, E.; Pozza, E.A.; Carvalho, J.G.; Montanari, M.; Guimarães, P.T.G.; Santos, D.M. Efeito do silício no controle da cercosporiose em três variedades de cafeeiro. Fitopatologia Brasileira, Brasília, v.29, n.2, p.185-188, 2004. 